\title{
Entropy Approach to the Study of Biological Activity of Chemical Compounds: The Other Side of Radioprotectors
}

\author{
Vladimir K. Mukhomorov
}

Agrophysical Institute, Sankt-Petersburg, 195220, Russia.

Email: vmukhomorov@mail.ru

Received 20 March 2011; revised 20 April 2011; accepted 27 April 2011.

\begin{abstract}
An attempt made to construct a model of relationship of the radioprotective and carcinogenic properties of biologically active compounds with their electron and information factors. We discovered a simple quantitative structure - activity relationships between the radioprotective effectiveness of chemicals and their molecular structure. It is established that carcinogenic properties of chemical compounds and effective radioprotectors are overlapping with each other. Within the framework of an information approach a systemic factor is proposed for distinguish highly radio protective agents among a series of drug. It was shown that the correlation obtained relating the structure of the compounds of the radio protective effect may be applied to studies of the mechanism of action of the preparations and for the purposeful synthesis of new chemicals.
\end{abstract}

Keywords: Radioprotector, Carcinogen, Information Function, Quasi-valence number

\section{INTRODUCTION}

Actual problem of modern chemistry of biologically active substances is the problem of creation of chemical compounds, effective such as antiradiation drugs. The basic requirements to these compounds are small doses, low toxicity and absence of collateral action. Presence of collateral negative effects essentially restricts practical applicability of radioprotectors. Purpose of this work to pay attention to possible linkage of chemical compounds bioactivity (for example, radioprotective action and carcinogenic activity) with their information properties and electron structure. Quantitative characteristics of this linkage are resulted.

Most rational methods are statistical ones at the decision of the problems linked with studying of action of set of factors on an organism. As the effect of interaction of preparations with biosystem depends on many conditions, it has the likelihood nature. Therefore at the analysis of linkage between molecular structure of a chemical compound and its biological action it is more preferable to use probabilistic, statistical models. The mathematical model cannot be used if the model is filled by a great number of insignificant characters. At the same time it is impossible to compensate the model lacks anything if the main link of the model is missed. Under condition of the highest possible simplification of a mathematical model the adequate model should reproduce studied properties of chemical compounds as much as possible close. Identification of the linkage between a chemical structure and biological action of chemical compounds not only allows to spend purposeful search of new chemical compounds but also promotes decode of the mechanism of their action. It creates a preconditions for development of main principles of creation of new effective preparations.

\section{RESULTS AND DISCUSSION}

Usually researchers use the experimental or physical-chemical information for revealing of linkage of biological activity with chemical structure of a preparation [1]. We use the approach is based on knowledge only the structural molecular formula of a preparation. Moreover the conclusion [2] is taken into account about importance of initial molecular structure of chemical compounds.

In this work the method is offered for revealing linkage between radio protective and carcinogenic properties of preparations with their molecular structure. The method uses the factorial attributes i.e. the mean quasi valence number [3] of a molecule $Z=\sum_{j} n_{j} Z_{j} / N$ and Shannon-Wiener information function [4]. Here $n_{j}$ is number of atoms $j$ with number of valence electrons $Z_{j}$ (i.e. electrons on an outer shell of atom). Summation is carried out on all atoms in a molecule. $N$ is the total 
number of atoms. In Table 1 two groups of active and inactive chemical compounds are resulted. The first group contain preparations with the expressed radio protective activity (survival rate of $50 \%$; these preparations are denoted by the sign + ). Preparations from the second group do not have property radio protective action even in very large doses (sign -). Parameter $Z$ statistically authentically separates the compounds having property radioprotective effect from compounds, not having radioprotective action. For preparations (Table 1) with expressed activity in a small dose $(<1 \mathrm{mM} / \mathrm{kg}$ ) parameter $Z \leq \bar{Z}=3.0$. Here $\bar{Z}$ is an average value round

Table 1. The information and electronic factors of chemical compounds and their radioprotective and carcenogenic activity.

\begin{tabular}{|c|c|c|c|c|c|c|c|c|c|}
\hline Compound & $\begin{array}{l}\text { Dose, } \\
\mathrm{mM} / \mathbf{k g} \\
{[7,12]}\end{array}$ & $\begin{array}{l}\text { Radio- } \\
\text { protec- } \\
\text { tion } \\
{[7,12]}\end{array}$ & Z & H, bit & Compound & Gross- formula & $\begin{array}{l}\text { Carci- } \\
\text { noge- } \\
\text { nicity } \\
{[13]}\end{array}$ & $Z$ & H, bit \\
\hline $\mathrm{H}_{2} \mathrm{~N}\left(\mathrm{CH}_{2}\right)_{4} \mathrm{CH}(\mathrm{NH})_{2} \mathrm{CH}_{2} \mathrm{SH}$ & 0.34 & + & 2.24 & 1.40 & Tetramethyl lead & $\mathrm{Pb}\left(\mathrm{CH}_{3}\right)_{4}$ & + & 1,88 & 1,01 \\
\hline $\mathrm{H}_{2} \mathrm{NCH}_{2} \mathrm{CH}_{2} \mathrm{NHCH}_{2} \mathrm{CH}_{2} \mathrm{SH}$ & 0.56 & + & 2.27 & 1.41 & Tetraethyl lead & $\mathrm{Pb}\left(\mathrm{C}_{2} \mathrm{H}_{5}\right)_{4}$ & + & 1,93 & 1,05 \\
\hline$\left(\mathrm{CH}_{2}\right)_{3} \mathrm{CNHCSNHCH}_{2} \mathrm{CH}_{2} \mathrm{OH}$ & 0.71 & + & 2.44 & 1.59 & Vinyl chloride & $\mathrm{C}_{2} \mathrm{H}_{5} \mathrm{Cl}$ & + & 2,00 & 1,30 \\
\hline $\mathrm{CH}=\mathrm{CCH}_{2} \mathrm{NHCH}_{2} \mathrm{CH}_{2} \mathrm{SH}$ & 0.10 & + & 2.50 & 1.78 & 1,2-Diethylhydrazine & $\mathrm{C}_{4} \mathrm{H}_{12} \mathrm{~N}_{2}$ & + & 2,17 & 1,22 \\
\hline$\left(\mathrm{CH}_{2}\right)_{2} \mathrm{CH}\left(\mathrm{CH}_{2}\right)_{5} \mathrm{NH}\left(\mathrm{CH}_{2}\right) \mathrm{S}_{2} \mathrm{O}_{3} \mathrm{H}$ & 0.07 & + & 2.55 & 1.60 & 1,1'-Dimethylhydrazine & $\mathrm{C}_{2} \mathrm{H}_{8} \mathrm{~N}_{2}$ & + & 2,20 & 1,65 \\
\hline $\mathrm{CH}_{3}\left(\mathrm{CH}_{2}\right)_{5} \mathrm{NH}\left(\mathrm{CH}_{2}\right)_{2} \mathrm{~S}_{2} \mathrm{O}_{3} \mathrm{H}$ & 0.29 & + & 2.56 & 1.63 & Bis-(chlorinemethyl) ether & $\mathrm{C}_{2} \mathrm{H}_{5} \mathrm{ClO}$ & + & 2,20 & 1,66 \\
\hline $\mathrm{H}_{2} \mathrm{C}=\mathrm{C}\left(\mathrm{CH}_{3}\right) \mathrm{CH}_{2} \mathrm{SC}(=\mathrm{NH}) \mathrm{NH}_{2}$ & 0.31 & + & 2.56 & 1.56 & Hydrazine & $\mathrm{N}_{2} \mathrm{H}_{4}$ & + & 2,33 & 0,92 \\
\hline $\mathrm{CH}_{3} \mathrm{NH}\left(\mathrm{CH}_{2}\right)_{3} \mathrm{NHCH}_{2} \mathrm{CH}_{2} \mathrm{SPO}_{3} \mathrm{H}_{2}$ & 0.31 & + & 2.61 & 1.80 & Aldrin & $\mathrm{C}_{12} \mathrm{H}_{8} \mathrm{Cl}_{5}$ & + & 2,38 & 1,53 \\
\hline $\mathrm{H}_{2} \mathrm{~N}\left(\mathrm{CH}_{2}\right)_{5} \mathrm{NCH}_{2} \mathrm{CH}_{2} \mathrm{SPO}_{3} \mathrm{H}_{2}$ & 0.62 & + & 2.61 & 1,80 & N-Nitrodiethylethylamine & $\mathrm{C}_{4} \mathrm{H}_{10} \mathrm{~N}_{2} \mathrm{O}$ & + & 2,47 & 1,55 \\
\hline $\mathrm{H}_{2} \mathrm{NCH}_{2} \mathrm{C}\left(\mathrm{CH}_{2}\right)_{2} \mathrm{CH}_{2} \mathrm{CH}_{2} \mathrm{SPO}_{3} \mathrm{H}_{2}$ & 0.62 & + & 2.61 & 1.80 & Aromit & $\mathrm{C}_{12} \mathrm{H}_{23} \mathrm{ClO}_{4} \mathrm{~S}$ & + & 2,49 & 1,64 \\
\hline $\mathrm{CH}_{2}=\mathrm{C}\left(\mathrm{NH}_{2}\right) \mathrm{CH}_{2} \mathrm{CH}_{2} \mathrm{SH}$ & 0.15 & + & 2.40 & 1,52 & Benzene & $\mathrm{C}_{6} \mathrm{H}_{6}$ & + & 2,50 & 1,46 \\
\hline $\mathrm{H}_{2} \mathrm{~N}\left(\mathrm{CH}_{2}\right)_{3} \mathrm{CH}\left(\mathrm{NH}_{2}\right) \mathrm{CH}_{2} \mathrm{SPO}_{3} \mathrm{H}_{2}$ & 0.21 & + & 2.61 & 1,80 & Dichlorobenzene & $\mathrm{C}_{6} \mathrm{H}_{4} \mathrm{Cl}_{2}$ & + & 2,50 & 1,46 \\
\hline Cyclo- $\mathrm{C}_{6} \mathrm{H}_{11} \mathrm{NHP}(\mathrm{O})(\mathrm{OH}) \mathrm{SH}$ & 0.19 & + & 2.64 & 1,82 & Auramine & $\mathrm{C}_{17} \mathrm{H}_{21} \mathrm{~N}_{3}$ & + & 2,54 & 1,30 \\
\hline $\mathrm{H}_{2} \mathrm{~N}\left(\mathrm{CH}_{2}\right)_{3} \mathrm{NHCH}_{2} \mathrm{CH}_{2} \mathrm{SPO}_{3} \mathrm{H}_{2}$ & 0.32 & + & 2.67 & 1,85 & 3,3'-Dirothylbenzidine & $\mathrm{C}_{14} \mathrm{H}_{16} \mathrm{~N}_{2}$ & + & 2,56 & 1,27 \\
\hline $\mathrm{H}_{2} \mathrm{NCH}_{2} \mathrm{CH}\left(\mathrm{CH}_{3}\right) \mathrm{CH}_{2} \mathrm{NHCH}_{2} \mathrm{CH}_{2} \mathrm{SPO}_{3} \mathrm{H}_{2}$ & 0.44 & + & 2.67 & 1,85 & 4,4'-Methylenedianiline & $\mathrm{C}_{13} \mathrm{H}_{14} \mathrm{~N}_{2}$ & + & 2,67 & 1,29 \\
\hline $\mathrm{L}(+)=\mathrm{H}_{2} \mathrm{~N}\left(\mathrm{CH}_{2}\right)_{4} \mathrm{CH}\left(\mathrm{NH}_{2}\right) \mathrm{CH}_{2} \mathrm{SPO}_{3} \mathrm{H}_{2}$ & 0.14 & + & 2.67 & 1,85 & Benzidine & $\mathrm{C}_{12} \mathrm{H}_{12} \mathrm{~N}_{2}$ & + & 2,69 & 1,32 \\
\hline $\mathrm{H}_{2} \mathrm{~N}(=\mathrm{NH}) \mathrm{CH}_{2} \mathrm{SSCH}_{2} \mathrm{C}(=\mathrm{NH}) \mathrm{NH}_{2}$ & 0.07 & + & 2.70 & 1,76 & Naphthylamine & $\mathrm{C}_{10} \mathrm{H}_{9} \mathrm{~N}$ & + & 2,70 & 1,23 \\
\hline $\mathrm{H}_{2} \mathrm{NCH}_{2} \mathrm{CH}_{2} \mathrm{CH}_{2} \mathrm{NHCH}_{2} \mathrm{CH}_{2} \mathrm{SPO}_{3} \mathrm{H}_{2}$ & 0.07 & + & 2.74 & 1,90 & N-Nitrosodimethylamine & $\mathrm{C}_{2} \mathrm{H}_{6} \mathrm{~N}_{2} \mathrm{O}$ & + & 2,73 & 1,60 \\
\hline $\mathrm{H}_{2} \mathrm{NC}(=\mathrm{NH}) \mathrm{NH}\left(\mathrm{CH}_{2}\right)_{3} \mathrm{NH}\left(\mathrm{CH}_{2}\right)_{3} \mathrm{SPO}_{3} \mathrm{H}_{2}$ & 0.08 & + & 2.74 & 1,90 & 3,3'-Methoxybenzidine & $\mathrm{C}_{14} \mathrm{H}_{16} \mathrm{~N}_{2} \mathrm{O}_{2}$ & + & 2,76 & 1,52 \\
\hline $\mathrm{H}_{2} \mathrm{NC}(=\mathrm{NH}) \mathrm{CH}_{2} \mathrm{SH}$ & 0.13 & + & 2.73 & 1,69 & Urethane & $\mathrm{C}_{3} \mathrm{H}_{7} \mathrm{NO}_{2}$ & + & 2,77 & 1,67 \\
\hline $\mathrm{H}_{2} \mathrm{~N}\left(\mathrm{CH}_{2}\right)_{3} \mathrm{NHCH}_{2} \mathrm{CH}(\mathrm{OH}) \mathrm{CH}_{2} \mathrm{SPO}_{3} \mathrm{H}_{2}$ & 0.82 & + & 2.77 & 1,89 & Benzanthren & $\mathrm{C}_{18} \mathrm{H}_{12}$ & + & 2,80 & 0,97 \\
\hline $\mathrm{CH}_{3} \mathrm{CONHCH}_{2} \mathrm{SS}\left(\mathrm{CH}_{2}\right)_{4} \mathrm{SO}_{2} \mathrm{H}$ & 0.17 & + & 2.81 & 1,79 & Chlorobenzylat & $\mathrm{C}_{16} \mathrm{H}_{14} \mathrm{Cl}_{2} \mathrm{O}_{3}$ & + & 2,80 & 1,58 \\
\hline $\mathrm{H}_{2} \mathrm{NCH}_{2} \mathrm{CH}_{2} \mathrm{SS} \mathrm{CH}_{2} \mathrm{CONH}_{2}$ & 0.60 & + & 2.84 & 1,87 & Yellow OB & $\mathrm{C}_{17} \mathrm{H}_{15} \mathrm{~N}_{2}$ & + & 2,80 & 1,33 \\
\hline $\mathrm{L}(-)=\mathrm{H}_{2} \mathrm{NCH}_{2} \mathrm{CH}_{2} \mathrm{CH}\left(\mathrm{NH}_{2}\right) \mathrm{CH}_{2} \mathrm{SPO}_{3} \mathrm{H}_{2}$ & 0.63 & + & 2.83 & 1,97 & Diacetylaminoazotoluene & $\mathrm{C}_{18} \mathrm{H}_{19} \mathrm{~N}_{3} \mathrm{O}_{2}$ & + & 2,81 & 1,52 \\
\hline $\mathrm{H}_{2} \mathrm{C}(=\mathrm{NH}) \mathrm{NH}\left(\mathrm{CH}_{2}\right)_{3} \mathrm{NHCH}_{2} \mathrm{CH}_{2} \mathrm{SPO}_{3} \mathrm{H}_{2}$ & 0.10 & + & 2.81 & 1,95 & Sudan II & $\mathrm{C}_{18} \mathrm{H}_{16} \mathrm{~N}_{2} \mathrm{O}$ & + & 2,81 & 1,40 \\
\hline $\mathrm{HO}_{2} \mathrm{~S}\left(\mathrm{CH}_{2}\right)_{4}-\mathrm{SSS}-\left(\mathrm{CH}_{2}\right)_{4} \mathrm{SO}_{2} \mathrm{H}$ & 0.06 & + & 2.97 & 1,72 & Safrole & $\mathrm{C}_{10} \mathrm{H}_{10} \mathrm{O}_{2}$ & + & 2,82 & 1,35 \\
\hline $\mathrm{H}_{2} \mathrm{O}_{3} \mathrm{PS}\left(\mathrm{CH}_{2}\right)_{2} \mathrm{NH}\left(\mathrm{CH}_{2}\right)_{3} \mathrm{NH}\left(\mathrm{CH}_{2}\right)_{2} \mathrm{SPO}_{3} \mathrm{H}_{2}$ & 0.35 & + & 2.97 & 1,96 & Ethylenethiourea & $\mathrm{C}_{3} \mathrm{H}_{6} \mathrm{~N}_{2} \mathrm{~S}$ & + & 2,83 & 1,73 \\
\hline $\mathrm{H}_{2} \mathrm{NCH}_{2} \mathrm{CH}_{2} \mathrm{SSCH}_{2} \mathrm{COOH}$ & 0.30 & + & 3.00 & 1,92 & Aminoazobenzene & $\mathrm{C}_{12} \mathrm{H}_{11} \mathrm{~N}_{3}$ & + & 2,85 & 1,40 \\
\hline $\mathrm{CH}_{2} \mathrm{~S}\left(\mathrm{CH}_{2}\right)_{3} \mathrm{NHC}(=\mathrm{NH}) \mathrm{CH}_{2} \mathrm{~S}_{2} \mathrm{O}_{3} \mathrm{H}$ & 0.19 & + & 3.00 & 1.93 & Propylthiouracil & $\mathrm{C}_{7} \mathrm{H}_{10} \mathrm{~N}_{2} \mathrm{OS}$ & + & 2.86 & 1.78 \\
\hline $\mathrm{H}_{2} \mathrm{NC}(=\mathrm{NH}) \mathrm{NHCH}_{2} \mathrm{CH}_{2} \mathrm{SPO}_{3} \mathrm{H}_{2}$ & 0.25 & + & 3.14 & 2.06 & Orange SS & $\mathrm{C}_{17} \mathrm{H}_{14} \mathrm{~N}_{2} \mathrm{O}$ & + & 2.88 & 1.42 \\
\hline $\mathrm{CH}_{2} \mathrm{CH}\left(\mathrm{NH}_{2}\right) \mathrm{COSH}$ & 11.4 & - & 2.77 & 1.82 & Sudan orange RR & $\mathrm{C}_{15} \mathrm{H}_{14} \mathrm{~N}_{4}$ & + & 2.88 & 1.40 \\
\hline $\mathrm{CH}_{3} \mathrm{CH}_{2} \mathrm{OCOCH}_{2} \mathrm{NHCSSCH}_{2} \mathrm{CH}_{2}$ & 5.07 & - & 2.80 & 1.77 & Acetamide & $\mathrm{C}_{2} \mathrm{H}_{5} \mathrm{NO}$ & + & 2.89 & 1.66 \\
\hline $\mathrm{H}_{2} \mathrm{C}=\mathrm{CHCH}_{2} \mathrm{NHC}(\mathrm{O}) \mathrm{SCH}_{2} \mathrm{COOHCH}_{2} \mathrm{CH}_{2}$ & 4.93 & - & 2.85 & 1.75 & Dibenzopyrene & $\mathrm{C}_{24} \mathrm{H}_{14}$ & + & 2.90 & 0.95 \\
\hline $\mathrm{H}_{2} \mathrm{NCH}_{2} \mathrm{CH}_{2} \mathrm{SC}(\mathrm{O}) \mathrm{CH}_{2}$ & 3.91 & - & 3.00 & 2.00 & Cicazin & $\mathrm{C}_{8} \mathrm{H}_{16} \mathrm{~N}_{2} \mathrm{O}_{7}$ & + & 3.03 & 1.72 \\
\hline $\mathrm{CH}_{2} \mathrm{CH}_{2} \mathrm{SC}(\mathrm{S}) \mathrm{NHCH}_{2} \mathrm{COOH}$ & 5.59 & - & 3.05 & 1.92 & Methylazoxymethanol & $\mathrm{C}_{4} \mathrm{H}_{8} \mathrm{~N}_{2} \mathrm{O}_{3}$ & + & 3.06 & 1.81 \\
\hline $\mathrm{HO}_{2} \mathrm{CCH}_{2} \mathrm{NHCONHCH}_{2} \mathrm{CH}_{2} \mathrm{SH}$ & 5.62 & - & 3.05 & 1.93 & Methylmethanesulfonate & $\mathrm{C}_{2} \mathrm{H}_{6} \mathrm{O}_{3} \mathrm{~S}$ & + & 3.17 & 1.73 \\
\hline Thionitynamides & 4.71 & - & 3.07 & 1.85 & Adenosine & $\mathrm{C}_{10} \mathrm{H}_{13} \mathrm{~N}_{5} \mathrm{O}_{4}$ & - & 3.20 & 1.85 \\
\hline $\mathrm{CH}_{3} \mathrm{SC}(\mathrm{O}) \mathrm{CH}_{2} \mathrm{CH}_{2} \mathrm{NHCONHCH}_{2} \mathrm{CH}_{2} \mathrm{SC}(\mathrm{O}) \mathrm{SCH}_{3}$ & 3 12.3 & - & 3.06 & 1.96 & Salicylic acid & $\mathrm{C}_{7} \mathrm{H}_{6} \mathrm{O}_{3}$ & - & 3.26 & 1.51 \\
\hline $\mathrm{HOCH}_{2}(\mathrm{CHOH})_{2} \mathrm{CH}_{2} \mathrm{NHCH}_{2} \mathrm{CH}_{2} \mathrm{~S}_{2} \mathrm{O}_{3} \mathrm{H}$ & 3.07 & - & 3.07 & 1.88 & Kvintocen & $\mathrm{C}_{6} \mathrm{Cl}_{5} \mathrm{NO}_{2}$ & - & 3.28 & 1.73 \\
\hline $\mathrm{HOCH}_{2} \mathrm{CHOHCH}_{2} \mathrm{NHCH}_{2} \mathrm{CH}_{2} \mathrm{~S}_{2} \mathrm{O}_{3} \mathrm{H}$ & 7.60 & - & 3.08 & 2.34 & Piperonyl & $\mathrm{C}_{8} \mathrm{H}_{6} \mathrm{O}_{3}$ & - & 3.29 & 1.46 \\
\hline 2-carboxy pyrrolidine-1-dithiocarbamic acid & 5.24 & - & 3.10 & 1.92 & Orange I & $\mathrm{C}_{16} \mathrm{H}_{11} \mathrm{~N}_{2} \mathrm{NaO}_{4}$ & - & 3.31 & 1.93 \\
\hline $\mathrm{BrC}_{6} \mathrm{H}_{4} \mathrm{O}\left(\mathrm{CH}_{2}\right)_{4} \mathrm{NHCH}_{2} \mathrm{CH}_{2} \mathrm{~S}_{2} \mathrm{O}_{3} \mathrm{H}$ & 2.13 & - & 3.11 & 1.88 & Dimethylsulfonate & $\mathrm{C}_{2} \mathrm{H}_{6} \mathrm{O}_{4} \mathrm{~S}$ & - & 3.38 & 1.74 \\
\hline $\mathrm{CH}_{3} \mathrm{OCOCH}_{2} \mathrm{CH}_{2} \mathrm{SO}_{2} \mathrm{CH}_{2} \mathrm{CH}\left(\mathrm{NH}_{2}\right) \mathrm{COOH}$ & 3.18 & - & 3.14 & 1.83 & Alizarin & $\mathrm{C}_{14} \mathrm{H}_{8} \mathrm{O}_{4}$ & - & 3.38 & 1.42 \\
\hline $\mathrm{H}_{2} \mathrm{NC}(=\mathrm{NH}) \mathrm{SCH}_{2} \mathrm{CH}_{2} \mathrm{CH}_{2} \mathrm{SO}_{3} \mathrm{H}$ & 10.1 & - & 3.14 & 2.02 & 2,4-Dinitrophenylhydrazine & $\mathrm{C}_{6} \mathrm{H}_{6} \mathrm{~N}_{4} \mathrm{O}_{4}$ & - & 3.50 & 1.97 \\
\hline$\left[\mathrm{H}_{2} \mathrm{NC}(=\mathrm{NH}) \mathrm{HCH}(\mathrm{COOH}) \mathrm{CH}_{3}\right]_{2}^{-}$ & 3.09 & - & 3.17 & 2.02 & Crimson & $\mathrm{C}_{20} \mathrm{H}_{12} \mathrm{~N}_{2} \mathrm{Na}_{4} \mathrm{O}_{7} \mathrm{~S}_{2}$ & - & 3.51 & 2.13 \\
\hline N-oxide 4-mercaptodihydro pyridine & 7.87 & - & 3.23 & 1.92 & Blue Evans’s & $\mathrm{C}_{34} \mathrm{H}_{26} \mathrm{~N}_{6} \mathrm{Na}_{4} \mathrm{O}_{14} \mathrm{~S}_{4}$ & ${ }_{4}^{-}$ & 3.51 & 2.14 \\
\hline $\mathrm{H}_{2} \mathrm{NCH}_{2} \mathrm{CHOHCH}_{2} \mathrm{~S}_{2} \mathrm{O}_{3} \mathrm{H}$ & 5.35 & - & 3.26 & 1.97 & 2-(2-furyl)-3-(5-nitrofuryl) acrylamide & $\mathrm{C}_{11} \mathrm{H}_{8} \mathrm{~N}_{2} \mathrm{O}_{5}$ & - & 3.54 & 1.79 \\
\hline $\mathrm{H}_{2} \mathrm{NCH}_{2} \mathrm{CH}\left(\mathrm{CH}_{2} \mathrm{OH}\right) \mathrm{S}_{2} \mathrm{O}_{3} \mathrm{H}$ & 4.81 & - & 3.26 & 1.97 & 6-Mercaptourine & $\mathrm{C}_{5} \mathrm{H}_{4} \mathrm{~N}_{4} \mathrm{~S}$ & - & 3.57 & 1.84 \\
\hline $\mathrm{CH}_{3} \mathrm{C}(=\mathrm{NH}) \mathrm{SCH}_{2} \mathrm{CH}_{2} \mathrm{CH}_{2} \mathrm{~S}_{2} \mathrm{O}_{3} \mathrm{H}$ & 5.08 & - & 3.08 & 1.89 & Yellow FCF & $\mathrm{C}_{16} \mathrm{H}_{10} \mathrm{~N}_{2} \mathrm{Na}_{2} \mathrm{O}_{7} \mathrm{~S}_{2}$ & - & 3.59 & 2.14 \\
\hline 2-furyl- $\mathrm{CH}_{2} \mathrm{NHC}(=\mathrm{NH}) \mathrm{CH}_{2} \mathrm{~S}_{2} \mathrm{O}_{3} \mathrm{H}$ & 4.00 & - & 3.36 & 2.05 & Amaranth & $\mathrm{C}_{20} \mathrm{H}_{11} \mathrm{O}_{11} \mathrm{Na}_{3} \mathrm{~N}_{2} \mathrm{~S}_{3}$ & $3-$ & 3.71 & 2.16 \\
\hline $\mathrm{H}_{2} \mathrm{NCONHCH}_{2} \mathrm{CH}_{2} \mathrm{~S}_{2} \mathrm{O}_{3} \mathrm{H}$ & 5.00 & - & 3.47 & 2.10 & Alizarin orange & $\mathrm{C}_{14} \mathrm{H}_{7} \mathrm{NO}_{6}$ & - & 3.71 & 1.72 \\
\hline$\gamma$-(S-purine) thiapropylsulfacid & 4.42 & - & 3.41 & 2.09 & Xanthine & $\mathrm{C}_{5} \mathrm{H}_{4} \mathrm{~N}_{4} \mathrm{O}_{2}$ & - & 3.73 & 1.93 \\
\hline $\mathrm{CF}_{3} \mathrm{CF}_{3} \mathrm{CH}_{2} \mathrm{OCOCH}_{2} \mathrm{CH}_{2} \mathrm{NH}\left(\mathrm{CH}_{2}\right)_{2} \mathrm{~S}_{2} \mathrm{O}_{3} \mathrm{H}$ & 3.00 & - & 3.82 & 2.27 & 1-[(Nitrofurfurylydin)-aminohydantoin & $\mathrm{C}_{5} \mathrm{H}_{5} \mathrm{~N}_{3} \mathrm{O}_{4}$ & - & 3.83 & 1.95 \\
\hline$(\mathrm{NC})_{2} \mathrm{C}=\mathrm{C}(\mathrm{SH})_{2}$ & 3.94 & - & 4.00 & 1.92 & 5-Nitro-2-furamidoxyn & $\mathrm{C}_{5} \mathrm{H}_{5} \mathrm{~N}_{3} \mathrm{O}_{4}$ & - & 3.76 & 1.97 \\
\hline 1,2,5 - thiadiazole-3- carboxylic acid & 7.69 & - & 4.46 & 2.25 & Alloxantin & $\mathrm{C}_{4} \mathrm{H}_{2} \mathrm{~N}_{4} \mathrm{O}_{8}$ & - & 4.33 & 1.92 \\
\hline 1,2,5- thiadiazole-3,4- carboxylic acid & 4.60 & - & 4.20 & 2.16 & Alloxan & $\mathrm{C}_{4} \mathrm{H}_{2} \mathrm{~N}_{2} \mathrm{O}_{4}$ & - & 4.33 & 1.92 \\
\hline
\end{tabular}


the sample of observations (the threshold value). At the same time the parameter $Z>\bar{Z}$ for the compounds without expressed protective action.

Let's determine the factor of association $\Phi$ [5] between radioprotective efficiency and value of the parameter $Z$. We use the statistical method of comparison of qualitative factors:

$$
\Phi=\frac{q_{11} q_{22}-q_{21} q_{21}}{q_{11} q_{22}-q_{21} q_{21}}=0.98
$$

Here $q_{11}$ is a quantity of the effective compounds having $Z \leq \bar{Z} ; q_{12}$ is a number of effective chemical compounds with $Z>\bar{Z} ; q_{21}$ is the number of non effective chemical compounds for which $Z \leq \bar{Z}$. Using (1) the asymptotic standard error of factor association is equal: $\operatorname{ASE}(\Phi)=0.5\left(1-\Phi^{2}\right) \cdot\left(1 / q_{11}+1 / q_{12}+1 / q_{22}+1 / q_{21}\right)=0.0 ;$ $\chi^{2}$ criterion gives [5]: $\chi^{2}=38.9 \square \quad \chi_{0.05 ; 1}^{(c r) 2}=3.84$.

Hence, chemical compounds with $Z \leq \bar{Z}$ and $Z>\bar{Z}$ belong different subset of set $Z$.

We carry out an additional check of a conjugation, using a graphic method of the median lines. As a result we obtain: $q_{11}=q_{22}=27$ and $q_{12}=q_{21}=3$. Using standard tables of bidimensional normal distribution we find, that $q_{11}=q_{22}>q^{(c r)}=20$ and $q_{12}=q_{21}<q^{(c r)}$ $=10$. Let's check up, whether distinction between mean values for active chemical compounds is statistically significantly different $\left(\bar{Z}_{1}=2.7, S_{1}=0.2, N_{1}=\right.$ 32) and non bioactivity chemical compounds $\left(\bar{Z}_{2}=\right.$ 3.25, $S_{2}=0.4, N_{2}=28$ ). $S_{1}$ and $S_{2}$ are standard deviations. Let's define by means of Fisher distributions the distinction between dispersions $F=S_{2}^{2} / S_{1}^{2}=4.0$ > $F_{27,31 ; 0.05}^{(c r)}=1.9$. Hence, variances one may assume the various. Therefore for comparison of mean values it is possible to use approximate $T$ criterion:

$$
\left|\bar{Z}_{1}-\bar{Z}_{2}\right|=0.55>T=\frac{v_{1} t_{0.05}(31)+v_{2} t_{0.05}(27)}{v_{1}+v_{2}}=0.17
$$

Here $v_{1}=S_{1}^{2} / N_{1}, v_{2}=S_{2}^{2} / N_{2}$. The fractile of magnitude $t=2.04$ which corresponds two degrees of freedom. Inequality (2) will mark that distinction between means $\bar{Z}_{1}$ and $\bar{Z}_{2}$ are statistically significant. Hence, active chemical compounds are grouped nearby $\bar{Z}_{1}$, and inactive ones nearby $\bar{Z}_{2}$.

The suggested method of selection of preparations is most effective for medicines which find out protective action at small doses $(\square \mathrm{mM} / \mathrm{kg})$ and are inactive even at very large doses $(\square \mathrm{mM} / \mathrm{kg})$. Nevertheless, some chemical preparations (Table 1 ) having $Z<\bar{Z}$, do not possess expected activity. It is possible to explain it various mechanisms of limitation of potential activity. One of possible mechanisms is discussed in work [6]. Here it is shown that only proper hydro- phobic property of the preparations probably maximum reflect of their biological activity.

Let's consider one of possible limiting mechanisms of radioprotective activity. Suppose we have the homologous series of chemical compounds $\mathrm{CH}_{3}\left(\mathrm{CH}_{2}\right)_{\mathrm{m}} \mathrm{NHCH}_{2} \mathrm{CH}_{2}$ $\mathrm{SSO}_{3} \mathrm{H}$, where $m=0,1, \cdots, 17$. As is known [7] these molecules have no effective radioprotective activity for $m=0-5$ and for $m=13-17$. N-substituted S-2-aminoethylthiosulfates are effective radioprotectors for $m=6-12$, however. Toxic properties of these molecules change at the same time. Only certain hydrophobic properties (P) molecules contribute to show ability of biological activity. Typically, this relationship has a parabolic dependence : $\mathrm{A}=a_{0}+a_{1} \pi+a_{2} \pi^{2}$. Here A is a bioactivity, $\pi=\log (\mathrm{P})$. Hydrophobicity of the homologous series was determined by method of additive increments [8]. The contribution of each group $\mathrm{CH}_{2}$ was assumed to be $\pi\left(\mathrm{CH}_{2}\right)=0.52$.

Figure 1 shows the variation of drug toxicity $\left(\mathrm{LD}_{50}\right)$ and radioprotection action (A, \%) of chemical compounds series of $\mathrm{CH}_{3}\left(\mathrm{CH}_{2}\right)_{m} \mathrm{NHCH}_{2} \mathrm{CH}_{2} \mathrm{SSO}_{3} \mathrm{H}$ depending on their hydrophobic properties. Relationship hydrophobicity $\pi$ with toxicity $\left(\mathrm{LD}_{50}, \mathrm{mM} / \mathrm{kg}\right)$ can be described by the regression equation which is close to a parabolic dependence

$$
\begin{gathered}
\mathrm{LD}_{50}=d_{1}+a_{1} \exp \left[-\left(\pi-b_{1}\right)^{2} / c_{1}^{2}\right] \\
a_{1}=34.8 \pm 0.84, b_{1}=5.96 \pm 0.05, c_{1}=-0.78 \pm 0.02 \\
d_{1}=1.05 \pm 0.28, \text { number of molecules } m=18 \\
R^{2}=0.94, F=12.0>\quad F_{1,17 ; 0.05}^{(c r)}=4.54 .
\end{gathered}
$$

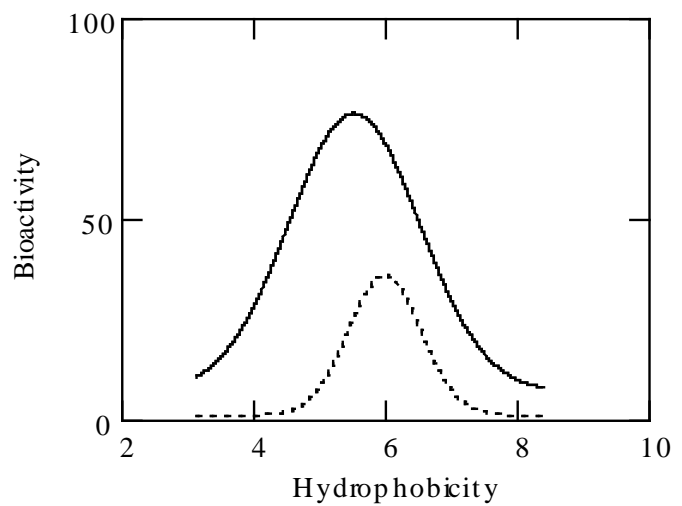

Figure 1. The bioactivity dependence of N-substituted S-2aminoethylthiosulfates on hydrophobic properties. — radioprotective activity (Eq.4)), - - - - toxic activity (Eq.3).

The Eq.3 describes correctly the dependence of biological activity of hydrophobic molecules to large and small values of $\pi$. The similar equation was obtained for the linkage of radioprotective activity $(A, \%)$ with hydrophobic properties of the homologous series of molecules: 


$$
A=d_{2}+a_{2} \exp \left[-\left(\pi-b_{2}\right)^{2} / c_{2}^{2}\right]
$$

$a_{2}=69.0 \pm 1.55, b_{2}=5.50 \pm 0.08, c_{2}=-1.40 \pm 0.06, d_{2}=$ $6.90 \pm 0.35$, number of molecules $m=18, R^{2}=0.85, F=$ $9.2>F_{1,17005}^{(c r)}=4.54$.

Toxicity of the molecules has maximum in the range of $\pi=5-7$ ( $m=10-14)$ (Figure 1). Maximum of radioprotective activity (A) is in this range of $m$.

Hence, molecules for $m>\underline{14}$ and $m<5$ (thus, for example, $m=15, Z=2.44<Z=3.0$ ) are likely to be potential radioprotectors. However, both toxic and radioprotective effect is limited by the hydrophobic properties of molecules.

The further research of linkage the structure of the chemical preparations that presented in the Table $\mathbf{1}$ has shown that electronic parameter $Z$ is associated with information function (entropy) of Shannon-Wiener [9,10]: $H=-\sum_{i} p_{i} \log _{2} p_{i}$; here $p_{i}=n_{i} / N$ at what $0 \leq p_{i} \leq 1$, and $\sum_{i} p_{i}=1$. Entropy function $H$ represents the integral characteristic of the object describing a measure of a molecular structure diversity. $n_{i}$ is a number of atoms of kind $i ; N$ is a number of atoms in molecule.

In this work is used Kolmogorov's combinatory approach [9] for information function definition. The quantity of the information in a molecule is turned out only function of number of finite elements of atoms set. Information measures are an integral index and are defined for the whole sets of events. It does not contradict representations about complex character of radioprotective action of radio protectors [10]. From Table 1 follows that mean value of information function for radioprotectors equals to $\bar{H}_{1}=1.79$ bit $\left(S_{1}=\right.$ 0.16). Whereas for the chemical preparations which are not possessing protective activity this function it is equal $\bar{H}_{2}=1.97$ bit $\left(S_{2}=0.15\right)$. Using $t$-criterion is easy for checking up, whether distinction of means information functions is statistically significant for $\bar{H}_{1}$ and $\bar{H}_{2}$. Using $t$-criterion we can examine the statistically difference for mean values of the information functions $\bar{H}_{1}$ and $\bar{H}_{2}$. Significant difference for mean values of the information functions $\bar{H}_{1}$ and $\bar{H}_{2}$

Let's preliminary define distinction between dispersions $S_{1}^{2}$ and $S_{2}^{2}$ by means of Fisher's criterion: $F=\left(S_{1} / S_{2}\right)^{2}=1.14<F_{31,29 ; 0.05}^{(c r)}=1.8$, that is distinction in dispersions is statistically insignificant. Therefore we can apply $t$-criterion:

$$
\begin{gathered}
\left|\bar{H}_{1}-\bar{H}_{2}\right|=0.18>t_{0.05} \cdot\left\{\left[\left(N_{1}-1\right) S_{1}^{2}+\left(N_{2}-1\right) S_{2}^{2}\right]\right. \\
\left.\cdot\left[N\left(N_{1}+N_{2}-2\right)\right]^{-1}\right\}=0.08
\end{gathered}
$$

Inequality (5) confirms the statistical significance of distinction for averages values $\bar{H}_{1}$ and $\bar{H}_{2}$. Thus, character $H$ as well as factor $Z$ allow to separate effective radio protectors from the preparations which are not having effective antiradiation actions.

We will verify the statistical significance of the stated hypothesis, using a statistical method of comparison of qualitative characters: $\Phi=0.77 \pm 0.07$, $\chi^{2}=35.6 \chi(8) 8 y_{05 ; 1}^{r)^{2}}=$. . Thus, statistical criteria $\chi^{2}$ confirm the existence of the linkage between character $H$ and biological activity of chemical preparations. Using methods of the statistical analysis it is possible to show that entropy is coupled with parameter $Z$, and the statistics will be following: the statistical sampling is $N=60$, the factor of linear correlation is $R^{2}=0.85$ $>R_{59 ; 0.05}^{(c r)^{2}}=0.22$, Fisher's criterion is

$$
F=99.8 \square \quad F_{1,58 ; 0.05}^{(c r)}=4.0 .
$$

These inequalities confirm the statistical significance of linkages between the characters $Z$ and $H$.

At the same time use of molecular characters $Z$ and $H$ for separating the carcinogenic preparations from non carcinogenic ones (in the Table 1 are noted by signs + and -, accordingly) also leads to statistically authentic results. Really, for most of carcinogens (Table 1 ) the character $Z \leq \bar{Z}$. For not carcinogens: $Z>\bar{Z}$. We have for information functions the following inequalities: и $H>\bar{H}^{\prime}$, accordingly. Here $\bar{H}^{\prime}=$ 1.6 bit is the mean value of information function for chemical carcinogens. Distinction of mean values of information function for the chemical preparations possessing carcinogen activity $\bar{H}_{1}=1.41$ bit and not possessing ones that $\bar{H}_{2}=1.86$ bit, even more, than in case of radio protectors. Hence, using $t$-criterion we obtain that chemical preparations for which $H \leq \bar{H}^{\prime}$ and $H>\bar{H}^{\prime}$ belong to different sets, and the threshold factor $\bar{H}^{\prime}$ is statistically significant.

Thus regions of the characters $Z$ and $H$ are overlapping with each other that obtained from different principles for carcinogenic chemical compounds and for effective radioprotectors. Hence, chemical preparations which are radioprotectors, can be carcinogen dangerous.

\section{CONCLUSIONS}

We have formulated two classification principles which obtained as a result of the statistical analysis of the experimental data using two kinds of biological activity. Hypothesis are verified by means of its test for chemical compounds which have not included in an initial series of the preparations. There are chemicals which have been examined both for radioprotective efficacy [10,11], and for carcinogenicity [12]. Dithia- 
carbamate $(Z=2.86, H=1.95$ bit) turned out an effective radio protector which gives full antiradiation protection at lethal doses of an irradiation and simultaneously this compound is carcinogen. Furthermore we have been investigated thiourea $(Z=3.0, H=1.72 \mathrm{bit})$, thiuram ( $Z=2.91, H=1.73 \mathrm{bit})$, reserpine $(Z=2.78, H$ $=1.51$ bit). Really, both electronic, and the information signs characterizing the chemical compounds, are covered between two bioactivities.

There is a simple quantitative structure - activity relationship between radioprotective effectiveness and carcinogenic properties of the chemical compounds. Ability of the parameters $H$ and $Z$ to separate potentially antiradiation drug and carcinogenic preparations from inactive chemical compounds clear the way to synthesis of new effective and safety drugs. We should know for this purpose only molecular structure of a chemical compound. As has shown the analysis, the offered method of selection of preparations is most effective for chemical compounds that possess protecttive action for small dose of chemicals.

\section{REFERENCES}

[1] Mukhomorov, V.K. (1984) Intermolecular interactions and biological activity of chlorine-containing molecules. Khimiko-Farmacevticheskii Zhurnal, Moscow, 18, 17-25.
[2] Mukhomorov, V.K. (1987) Statistical aspects of linkage of radioprotective action of derivatives mercaptoethylamine and its analogues with their electronic parameters. Khimiko-Farmacevticheskii Zhurnal, 21, 1210-1215.

[3] Bonchev, D. and Trinajstič, N. (1977) Information theory, distace matrix, and molecular branching. Journal of Chemical Physics, 2, 392-397.

[4] Veljkovič, V., Lalovič, D. (1973) General model pseudopotential for positive ions. Physical Letters A, 45, 59-62.

[5] Főrster, E. and Rőnz, B. (1979) Methoden der Korrelations und Regressionsanalyse. Verlag Die Wirtshaft.

[6] Mukhomorov, V.K. (1988) Entropy function and radioprotective efficacy of N-substituted S-2-aminoethylthio sulfates. Radiobiology, 28, 407-411.

[7] Sweeney T.R. (1979) Survey of compounds from the antiradiation drug development programm. Washington.

[8] Leo, A. Hansh, C. and Etkins, D. (1971) Partition coefficients and their uses. Chemical Review. 71, 525-674.

[9] Quastler, H. (1953) The alphabet of the information. Information Theory in Biology. H. Quasler Ed., Pergamon Press, London - New York - Paris - Los Angeles, 46, 3-35.

[10] Alexeyev, V.L. and Levich, A.P. (1997) A search for maximum species abundances in ecological communities under conditional diversity optimization. Bulletin of $\mathrm{Ma}$ themati Biology. 59, 649-677.

[11] Kolmogorov, A.N. (1987) Theory of information and theory of algorithms. Nauka, Moscow, (in Russian).

[12] Romantzev, E.F. (1968) Radiation and chemical protection. Nauka, Moscow, 1968 (in Russian).

[13] Turusov, V.S. (1964) Cancerogenic substances. Handbook. Nauka, Moscow, (in Russian). 